D519 


\section{SF 523.D519}

Melvil Dewey's bibliographic decimal sys

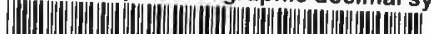

31924003207176

\section{ALBERT R. MANN}

LIBRARY

New York State Colleges

OF

Agriculture AND HOME ECONOMICS

AT

CORNFLL UNIVERSITY

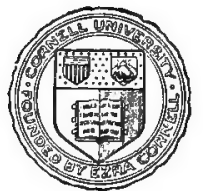

EVERETT FRANKLIN PHILLIPS

BEEKEEPING LIBRARY 


\section{MELVIL DEWEY'S}

\section{Bibliographic Decimal System}

AND

\section{ITS PROPOSED APPLICATION}

FOR THE

\section{ARHANGEMENT AND RAPID SEARCH OF SCIENTIFIC SUBIECTS \\ CONTAINED IN}

Beo-journana.

(6381.09)

Translated by:

G. HAMILTON LRCPI. LRCSI

and

E. F. BURTON.

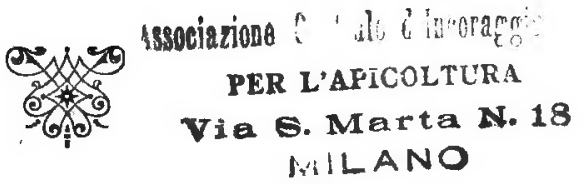

BORDTGHERA

Printed by P. Gibelli

1902 


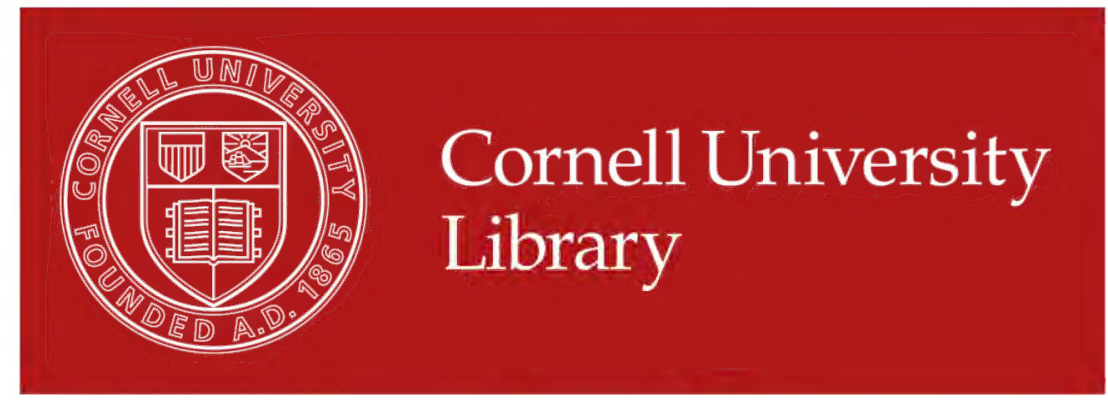

The original of this book is in the Cornell University Library.

There are no known copyright restrictions in the United States on the use of the text. 



\title{
Melvil Dewey's
}

\section{Bi6tiographic Decimat System}

AND

\author{
ITS PROPOSED APPLICATION
}

FOR THE

\section{arrangement and rapid search of scientific subjects contained in Bee-Journals} (6381.09)

(Mr W. F. REID, Member of Council, and First Class Expert of the British Bee-Kecper's Association, has kindly given the translators the benefit of his technical knowledge and reviscd the transiation).

T. MARRE,

ENGINEER.

Two years agn, while lookin:s over some copies of our woll known agricultura! periodical "Il Collivalore" edited by Dr EDoardo Ortavi, my attention was called to an article by Dr A. Micheli, written from Rome, entilled: dgricultural Bibliography and the decimal systein of Mcluil lowey (016.63). The use of the word decimal in connection with hi'sligraphy and the number (016.63) under the title, set m' wduduring from my object and led me to read the alticle in question giving in general idea of the system. Having read it, I came to the conclusion that tha system, with study, might be made us sul, not only for classifying books in large libraries, or in large bibliographical calalogues, the main object of the system; but also for classifying alld easily finding the various scientific subjerts scattered over most periodicals. So also with regard to apiculture. 
While lonking through the copies of the "Coltivatore" I felt the truth of what Dr Mrcheli had fully dealt with in his article, namely: The great rush which pervades everything at the present day : the hurry and running so as to lose as little time as possible.

Occupied wilh these thoughts and the desire to see this system applied to the periodicals, according to their conlents, I applied to the Bruxelles International Bibliographical Institute for the classifying tables for agriculture, and was informed that the tables were in course of preparation and that Mr Versorec had been appointed for the work. I obtained these tables last year and now I place them before my bee keeping colleagues, with the hope that at least with regard to the branch relating to apiculture, my desires before referred to may be realized.

Before making my proposal and explaining the classification tables, I will give some idea of the bibliographic decimal system and explain the tables proposed by the distinguished Agricultural Scientist V. Vermores, for the classification of the writings of that portion of agriculture which relites to bee-keeping.

The system of decimal classification was applied to bibliography by Melvil Dewey, on $\theta$ of the most distinguised American bibliophiles.

This system has already been adopted for the bibliographic classification relative to medicine, astronomy, geog raphy, philology, sociology, music and mathematics.

The decimal classification of bibliographic documents is obtained by means of classifying numbers formed by the 10 arab figures of the decimal numeration completed by a certain number of signs of union, abbreviation and composiiton.

To establish the series of classifying numbers, the whole of what constitutes human knowledge was divided into groufs, forming ten principal classes, each of which is represented by one of the 10 figures in the decimal form, namely with the decimal figures from 0 to 1 in the following way:

0. General works.

0.1 Philosophy.

0.2 Religion, - Theology.

0.3 Social science. - Jurisprudence.

0.4 Philology. 
0.5 Natural science.

0.6 Useful arts - Applied stience - Technology.

0.7 Fine arts.

0.8 Literature.

0.9 History and Geography.

Each of these classe: was then divided into ten more subdivisions which include all the intellectual works belonging to that class, and as we are only concerning ourselves with the class dealing with apiculture, namely class 0.6 , we find it coming within the figures 0.60 to 0.69 :
0.6 Uselul arts - Applied science - Technology.
0.60 Generalities.
0.61 Medicine.
0.62 Engineering.
0.63 Agriculture.
0.64 Domestic economy.
0.65 Commerce - Transport.
0,66 Chemical industries.
0.67 Manufactures.
0.68 Mecanichal industries and trades.
0.69 Buildings.

Each of these subdivisions was divided again into 10 further subdivisions and so on, and thus an encyclopedic classification, of which each special science forming part of the whole human knowlelge capable of being represented by a specilied fraction, was obtained and subdivided into smaller fractions similarly specified, or to be specified, all being united to each other in regular order.

Dividing then each group into 10 other groups, or subdivisions, which include all the works belonging to that division, and considering only in the tables that with which we are concerned, we see that agriculture 0.63 was also in its turn subdivided into 10 other divisions, from 0.630 to 0.639 embracing all subjects on agriculture. So we find the branch apiculture numbered 0.638 , includin.r apicullure and silk-worm cullure.

All this knowledge, represented by the number 0638 (apicul. ture-silk-worm culture) was again subdivided; to apiculture and bees being assigned the first place, namely 0.6381 . 


\section{Summing up :}

All publications dealing wilh useful arts are contained in the group numbered . . . . . . . . . . . . 0.6

Having divided the useful arts into 10 groups, those dealing with agriculture come under the number . . $\quad 0.63$

Having divided the group of agriculture into ten divisions, the one that treats of apicullure and silk-worm culture comes under the number

0.638

This last being again divided into ten subdivisions, the one which treats ôf apiculture and bees, being numbered . 0.6381

Therefore in a library arranged according to the decimal classification, all works referring purely and simply to hee literature carry the number 0.6381 , or a number with some decimals beginning with these four figures which are characteristic of the special branch: Apiculture-Bees.

Therefore in one of these libraries, arranged according to the decimal system, on asking for all the works classified with the fraction beginning 0.6381 , we are sure to obtain all publications on Apiculture and Bees in that library.

I think that these observations are sufficient to show the clearness and simplicity of the decimal classification; it has also ollier advantages:

$\mathbf{1}^{\text {st }}$ Subdividing the subjects into classes one can trace their origin with precision: the idea is simple: it is sufficient to start from the trunk, or the first division travelling up the branches or the successive divisions, each branch gradually getting smaller, till ore reaches the desidered point, without difficulty, and sure of having left nothing behind.

$2^{\text {nd }}$ The classifying numbers represent ideas, not words; and this constitute a real international bibliographical language.

In all libraries of the world, the number 0.6381 will represent. bee-culture, bees. To render the bibliographic works accessible in all countries, in whatever language they are, it will be sufficient if the tables be translated.

$3^{\text {rd }}$ The decimal clissification may be indefinitely exlended, even to include all the knowledge of the future. When it becomes necessary to divide some subject into new subdivisions, to these can be appointed classifying numbers, formed in the usual way, by the addition of decimals. 
On account of these advantages, the Brixelles International Bibliographic Institute, the highest authority on bibliography, has adopted Dewey's system for its classifying tables.

This Institute which has been working for nearly seven years at this classification of the universal bibliographic cataloguo, is largoly aiding in propagating the extension of this system, so, in future, all general and special bibliographies of all nations should be made in accordance with this system.

They can thus be made use of for the above mentioned universal catalogue, and scientific productions of any nation can be ascertained by any other nation.

The enterprise of the Bruxelles Central Office was not limited to this course only, for on finding that Dewey's classifying tables wêre incomplete, in consequence of having been" drawn up, as Michel suggests, by one man alone, who could not have a complete knowledge of the whole of the information constituting human knowledge, the Institute employed several distinguished authorilies in various countries to amplify these tables.

For instance there was no agricultural bibliography, nor could this be made from Dewey's, as he had only given the first general division of 10 groups. It was in consequence of this defect that the Instilute in 1899 appointed Mr Verwores of Villefranche, director and founder of the wine gruwing establishment of that district, to prepare the taisles on atgricultural sciences, according to the above mentioned system; a work which, with the assistance of Messrs GuilJe, C. Michaut, Dr Letelier and Miss Jullieron, he completed and publistred in February 1900 under the title of "Manuel du Répertoire bibliographique des sciences agricoles, élabli d'après la classification décimale", par V. Vermorel (C2J.4:63).

Selecting from that catalogue, that which refers to apiculture, the following are the tables we find:

\section{Agriculture.}

63.8 Les insectes utiles à l'agriculture. - Apiculture. Sériciculture.

63.81 Apiculture. - Abeilles.

(Pour la physiologie et l'anatomie des abeilles, voir 595,79). 
63.81 (0) Giénéralités. A diviser comme 63 (0).

63 (0) Généralités sur l'Agriculture.

63 (01) Théorie de l'Agriculture. La science agricole, son rôle, son progrès.

63 (001) (.) Monographies agricoles ginérales. Exploitation agricole.

63 (02) Traités d'Agriculture.

63 (021) Grands traités.

63 (022) Moyens traités. Éléments. Manuels. Aide-Mémoires.

$63(023)$ Pótits traités ou rudiments.

63 (03) Encyclopédies. Dictionnaires agricoles.

63 (031) Grandes encyclopédies. Grands dictionnaires.

63 (032) Moyennes encyclopédies. Moyens dictionnaires.

63 (033) Petites encyclopédies. Pelits dictionnaires.

\section{3 (04) Essais d'Agrioulture. Conférences sur l'Agriculture.}

63 (05) (.) Périodiques agricoles (Revues, Annales, Bulletins, Journaux). Classer ici, par duplicata, les Bulletins des Sociótés agricoles.

$63(058)$ Annuaires. Agendas agricoles.

63 (059) Almanachs agricoles.

$63(06)$ (.) Sociétés agricoles.

63 (061) Institutions officielles (Commissions, Comités, Conseils).

63 (062) Sociélés libres d'agriculture, leurs annales, bulletins, compte-rendus, etc., toutes jublications y relatives.

63 (062.1) Sociétés nationales et généralcs.

63 (082.2) Sociélés régionales. Comices.

6.3 (062.3) Syndicats (Toir 331.881).

63 (063) (.) Congr'è agricoles autres que ceux des Sociétés.

- (063.1) Congrès internationaux.

. (063.2) Congrès nationaux.

(*) Riporto, cone è nel Manuale, la tavola $63(0)$. 
63 (064) (.) Expositions agricoles.

- (061.1) Expositions générales et internationales.

. (06't.2) Exposilions régionales.

63 (07) (.) Enseignement et étude de l'Agriculture.

63 (071) Écoles d'ayriculture. Chaires d'agricullure. Instituts agronomiques. Tous renseignements et publications y relatifs.

63 (072) Laboratoires agricoles. Champs d'expériences. Stations.

Fermes expérimentales. Leurs publications.

- (07:.1) Laboraloires agricoles.

- (072.2) Clamps d’expériences et de démonstration.

(07.2.3) Slations agricoles.

. (07.2.4, Fermes expérimentales.

63 (074) Musées, vollections se rapportant à l'agriculture.

63 (075) Manuels classiques d'agriculture.

63 (077) Méthodes d'enseignement de l'agriculture.

63 (079) Concuurs, primes, subsides, bourses, et autres moyens d'encouragement à l'agriculture.

63 (079.1) (.) Concours agricoles.

.(079.11) Concoul's généraux.

.079.12) Concours régionaux.

. (079.121.) Rapports des primes d'honneur.

. (079.13) Concours spéciaux. Essais publics.

63 (079.3) Excursions, explorations, missions, voyages agricoles.

63 (079.5) Ênquêtes agricoles.

\section{08$)$ Polygraphies agricoles.}

63 (081) Pulygraphizs individuelles.

63 (082) bolysiaphies collectives.

63 (082.2) Antologies Agricoles.

$63(09)$ Histoire de l'Agriculture.
A) Dans tous les pays, à toutes les époques
$63(09)$
$B)$ A toutes les ipoques, mais localisée
$63(09)($.
C) I)ans tous les pays, à une certaine époque
D) Liınitée à un pays et à une époque
$63(09)$ " )
$63(09)($.$) " 》$

63 : 016 Bibliographies agricoles. 
63 : 31 Statistiques agricoles.

63 : 34 Législation agricole.

63 : 35 (.) Administration de l'Agriculture. - Minislères de l'Agriculture. - Leurs publications.

$63: 38$ (.) Le commerce des produits de l'Agri-
culture.

63 : 54 Chimie agricole (Voir aussi 581.19 , chimie végétale).

63 : 55 Géologie agricole.

$63: 551.5$ Météorologie agricole (Voir aussi 62.21).

63 : 58 Botanique agricole.

$63: 58.16$ Botanique économique agricole (Voir 63).

63 : 59 Zoologie agricole.

63 : 59.16 Zoologie économique agricole (Voir 63.2, 63.6).

63 : 59-57-16 Entomologie agricole (Voir aussi 63.27 et 63.8 ).

63 : 66 Les industries dérivées de l'Agriculture.

63 : 69 Les constructions rurales en général.

(Voir aussi 728 pour les questions spéciales).

63 : 92 Biographie collective des Agriculteurs.

63.81.0 Procédés d'élevage et d'exploitation des abeilles.

63.81.01 Formation des colonies d'abeilles.

63.81.02 Variétés, races d'abeilles.

63.81.03 Procédés de reproduction.

.032 Croisement. Métissage.

.034 Ponte. Essaimage.

63.81.04 Procédés d'élevage des abeilles.

.043 Alimentation. Matières récoltces et élaborées.

63.81.053 Exploitation des produits (Voir 63.77).

63.77 Le miel. La cire.

63.771 Le miel.

63.771 : 38 Commerce du miel.

63.771.001 Caractères et propriétés du miel.

63.771.0022 Préparation du niel.

.00221 Procédés d'extraction. 
63.771.0023 Elléments constitutils, matière première du miel. Nectar. Pollen.

63.771.0025 Appareils pour la préparation du miel. .0025 .1 Mélo-extracteur solaire.

$.0025 .2 》$ centrifuge.

.0025 .9 Autres appareils employés.

63.771.0041 Utilisation et consommation du miel.

(Voir à 642, fabrication des pains d'épices). .0043 Transport du miel. $.00+4$ Conservation (cristallisation). Récipients employés. .0046 .2 Altération du miel.

63.771.1 Les différentes sortes de miel.

A diviser d'après 63. Ex: 63-771.1-331.53. Le miel de sainfoin. 63.771.1-41. Le miel d'arbres fruitiers.

1 diviser aussi par régions : 63.771 .1 (23). Le miel de montagnes. 63.771 .1 (25) $\Rightarrow$ de plaines. $63.771,1$ (44.1) $\gg$ de Bretagne.

63.771.11 Miel coulé.

.12 Miel en rayons ou en gâteaux.

63.771.3 Les succédanés et falsifications du miel.

.771 .31 Miels additionnés de glucose ot autres matières. .771 .32 Miel produit par des abeilles nourries arer des sirops spéciaux.

63.771.4 Lues produits dérivés du miel.

.771 .41 Hydromel et sa fabrication.

.771 .42 (Enomel " "

.771 .43 Vinaigre du miel "

.771 .44 Eau-de-vie lo miel „

.771 .49 Autres dérivés.

63.772 La cire ،d'abeilles.

$63.772: 38$ Commerce de la cire.

63.772.001 Caractères et propriétés.

.0022 Préparation.

.0022 .1 Fusion.

.0022 .2 Purification.

.0022.3 Blanchiment.

.0022 .4 Moulage.

.0025 Appareils pour la préparation de la cire.

.0035 Prix de vente de la cire.

.0011 Utilisation industrielle de la cire.

63.772.1 Différentes sortes de cire. 
63.772.3 Les succédanés de la cire l'abeilles.

.772 .31 Cires dorigine végélale.

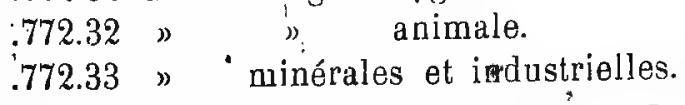

63.81.06 Installations, matériel apicoles. Le rucher.

.061 Les ruches.

.062 Instruments apicoles.

63.81.07 Peuplement et conduite de rucher.

63.81.08 Procédés de capture des essaims et colonies sauvajes.

63.81.09 Maladies et ennemis des abeilles.

.091 Maladies proprement dites.

.091.1 Loque ou pourriture du couvain.

.092 Ennemis.

.092 .1 Insectes nuisibles.

.092 .2 Oiseaux.

.092.3 Mammifères.

.092 .4 Plantes nuisibles (qui retiennent les abeilles).

Regarding the divisions of Apiculture and Bees published by M. Vermores one is easily silisfied that they do not quite answer to the nature of bee-science and to the subjects connected with it; nor can one find in them those special lines which subdivide and must clearly. subdivile onr scien e and industry, as is done for all that constitutes human knowledge in Dewey's first tables of classification and as this decimal system is intended to do. If we examine into this defect we readily perceivo that it has originated owing to M. Vermores having aimed at subdividing the various sciences or conceptions relating to animal life in nearly the same, or analogous terms, whilst if it is known that all these sciences have points in common, it is not less true that they largely divorge in their development; the very duration of life which for certain beings may be a point of absolute and definite demarcstion, is not so for others, even if their more or less high state of development be not taken into account, and even the technical language applicable to these points in common differ; therefore an altempt to empluy the same expressions, the $\operatorname{sam} \theta$ titles to indicale the general lines that must divide and subdivide 
the mass of knowledge appertaining to these sciences or conceptions, must only deprive the chief divisions of clearness and accuracy, and "create great difficulty in the aclual work of assigning classifying numbers to the memorandum or publication.

It would therefore be desirable to modify VenMorel's tables taking into consideration the views I have already expressed.

With regard to Apiculture and Bees - the object I have in view is to propose a system which when used in connection with the various bee-culture periodicals, the several subjects treated in them may bo more clearly shown, so that the beekeeper may, at the end of the year, at a glance, find them. I propose therefore that Vermorel's tables which I have largely adopter should be modified and the following tables which seem to mo capable of containing all known production connected with this stience, made use of. But in doing this, in order that any doubt in the assigning of the classifying number may be lessened, the division of the various subjects relating to this industry should be carried out in the special way usually adapted by specialists and writers in this branch of science.

These tables, which do not lake up much space, should be printed in pampletet form yearly or at the beginning of every periodical and it would bo desirable that every author of an article should place below the title, the classifying number adapted to his work, as I hase myself done today.

The classifisation of a wriling, made in this way, would attain great precision, as it would be made by those who would know exaclly the principal subject of the writing, and therefore the place to be assigned to it in the clussification.

For the use and application of these tables, only the following few, simple rules are necessary: and it is better they should be few and simple so that they may be easily and without error, carried out.

First of all, as all knowledge on bees must be in the group 0.6381 , these first decimal numbers need only be shown once on bee-journals, for instance on the cover, and afterwards understood or indicated by the sign $"$. or even simply a dot. Thus on seeing written $» .2 \div 3$ it would mean 0.6381.243. 
The dot is inlended to make the reading easier and the various zroups clearer, thus:

0.6381 .24 .3 indicates that the group 0.6381 belongs to apiculture and bees, 0.6381 .24 indirates the group implements for working in hives and handling lees, and 0.6381.24.3 the group gloves and veils.

In drawing up the index of periodicals, the numbers should always be placed in order of magnitude from the lowest to the highest, and always considered as decimals, thus: 2.24 is smaller and should be placed before ". 245 and this again before ". 27 .

When an article or memorandum includes several subjects belonging to various classifying numbers, all these numbers should be separated by the sign + , thus one would mark ". $17+$ .953 for a memorandum dealing with sulla (Flora) and the quality of honey gathered from it (Honey).

These articles would appear twice in the index with each of the two respective numbers, as if the article had been published once with one number and once with the other.

Besides when compiling an index the tille of the article or memorandum should be written after the classifying number, because this number only would be used, so that one might find what is required at a glance, without having to read so many titles as is now necessary, which have not even a remote connection wilh what one is seeking. After the tille, naturally, comes the page as usual.

It would be of the greatest value to bee-keeper's, if some one would c mpile such an index of all periodicals on apiculture of the past. This would aftord great value to all the contents of the periodicals, because with such a work, not of many pages, the usefulness of those contents would become much greater, being accessible to ever a not very patient student, who could, at a glance, pick out what would be useful for his studies.

It is well to noto here that the classifying number in the various periodicals is nol only useful for rapidly finding in the index the subject required, but also for any one wishing to read the extracts generally written without a title, the above menti-i oned number serving as a concise title, after a little practice has been acquired in the use of the tables. For instance if an extract be marked (.8), one would at once know that the article so marked treals of the formation of bee colonies. 
These are the tables I propose for the subject in question:

\section{TABLES of BBBLOCGAPHHC DECIMAL CLLSSFFICATION}

for publication relating to BEE-CuLTURE and BeES

\section{FIRST DIVISION.}

\subsection{1 - Apiculture and Bees.}

0.6381. 0 General memoranda. Treatises. Lectures. Teaching. History. Statistics. Bibliography.

». 1 Theoretical part of apiculture. Systems of apiculture. Natural history of bees, their varieties and species: their habits, requirements, their means of comunication. Brood, diseases, enemies. Combs, manner of regulaling the construction of same. Flora connected with beerculture. (See produce of bees at $\$ .9$ ).

». 2 Apiculture apparatus. Varieties of hives. Frames. Wax foundation. Apiaries. Discourses in connection with same.

ఐ. 3 Various methods of handling bees, opening hives, finding the Queen, young and old bees. Bee-sting, its remedies and therapeutical effects.

». 4 Methods of uniting oolonies. C'are of queenless families. Strengthening of weak stocks.

». 5 Methods of favouring or preventing the increase of stocks. Feeding, when stores deficient or stimulating. Robbing.

». 6 Care of stocks during the year. Profits of bee-keeping. Enlargement of brood nest. Spring and autumn inspection. Wintering. Honey harvest.

».7 Rearing and changing Queens. Cutting out and inserting Queen cells. Inlroduction of strange Queens and Queen cells. 
». 8 Formation of bee-colonies. Nitural and artificial swarms; hiving and trealmenl; methods of preventing swarming. Means of limiling the number of storks. Im proving tho race. Seleclion of breed"s.

„. 9 Trade rulating to bees. Transfering bees. Agricultural effects and beemproduce. Uses and application of these and heir trade value. Bee chemistry and.meteorology.

\section{SUCCESSIVE DIVISIONS.}

0.6381.0 General memoranda. Treatises, Lectures. Teaching. History. Statistics. Bibliography.

".01 General Memoranda and rerorts of bee-culture and bees. General vearly repurts of bee-keepers.

„.02. Works and text books on bee-culture. ".021 for bee-culture with fixed combs;

$" .022 " \Rightarrow$ moveable combs;

$" .023 "$ " fixed and moveable combs.

.03 Bee-keeping dictionaries.

"04 Various notices, letters, lectures, poetry, speeches and various conferences on bees.

n.041 Various notices.

מ.042 Lelters.

».043 Lectures - Speeches.

ఐ044 Conversazioni.

».045 Poetry.

".05 Bee periodicals. (Reviews, Annals, Bullet'ins, Journals, Yearly returns, Agenda and bee almanacs).

“.06 Boe societies. Institulions. Commissions. Committies. Councils. Meetings. Syndicales. Congresses. Bee exhibitions.

".07 Toaching. Schools. Professorships. Museums: Bee-culture observatories and publications thereof. Voyages. Researches. Competitions. Subsidies and other methods of encouraging bee-culture.

».08 Papers Concerning bees. 
„.09 Hislory of apiculture. Articles relating to same for various countries and periods. Statistics. Bibliography, Legislation. Administration.

»1 Theoretical part of apiculture. Syslems of apiculture. Natural history of lees, their varieties and - species; their habils, requirement, their means of comunication, Brood, diseases, enemies. Combs, manner of regulating the construction of same. Flora connected with bee-cul ture. (See produce of bees at $» .9$ ).

".10 Generalilies, namely generul articles on the theory of bee-culture, bees and flöra.

»11 The bee family. Physiology. Anatomy. Reproduction:Brood. Development. Life. Feeding. Needŝ. Instincts.

".111 The bee family. Various species of bees.

». 1111 Queen bee.

D. 1112 Drone.

». 1113 Worker.

》. 1114 Fertile worker.

ग.112 The senses of the bee.

".113 Anatomy of the bee.

»114 Brood.

»115 Metamorphoses. Reproduction.

»116 Development and life of bess and observations in connection therewith.

»117 Parthenogenesis.

".118 Customs, instincts, habits, needs and special characters of the three classes of bees and observalions in connection therewith.

".119 Bee's faculty of orientation. Radius of flight.

»12 Various methods of apiculture, with fixed or moveable combs, mixed method, migratory.

„13 Language and the internal and external signals of bees and colonies.

n.14 Combs, various cells. Methods of regulating their construction, store combs.

".15 Hygiene of combs and hives. Diseases of bees. Remedies.

»16 Enemies of bees, animal and vegetable. The destruction of these enemies.

»17 Flora connected with bee culture. 
„. 2 Bee-keeping appliances. Varieties of hives. Frames. Wax foundations. Apiaries. Discourses in connection with same.

»20 Generalities.

„.21 Bee-hives and their parts.

".211 Hives with fixed combs.

$.212 "$ " moveable combs.

ग.2121 With fixed roof.

D.2122 $)$ moveable roof.

".21 23 " frames attached to the roof.

$» .2124$ free frames.

":13 Hives of variqus and mixed systems.

๗2'14 Observatory hives, for rearing queens, for despatching swarms.

».215 Entrance and covering of hives, defences, cushions, blankets, quilts.

»216 Various frames. Discussions in connection with them.

».22 Appliances for working in hives, and handling bees.

n.221 Smokers.

n222 Pincers. Scrapers, stands, cases for packing frames carts for travelling bee-culture.

ᄁ.223 Gloves, veils.

".224 Implements for fixing combs in the frames. Fasteners.

12.225 Starters. Wox foundation, machines and methods of making it, implements for fixing it in the frames.

1.2:6 Feeders. Drinking vessels.

»227 Queen cages.

$¥ 228$ Queen nurseries.

1.229 Various.

".23 Swarm catcher - Automatic hiving apparatus.

„.24 Appliances for destroying bee enemies.

»25 Appliances for exlrasting honey.

„2ذ1 Knives, uncapping knives.

".252 Stands for uncapping,

».253 Extractors.

»254 Presses.

》.255 Filters. 
".26 Appliances for extracting wax.

»261 Solar wax-extractor.

».262 Presses.

»263 Special boilers.

»27 Apiaries, their situalion, construction, disposition.

". 3 Various methods of handling bees, opening hives, finding the Queen, young and old bees. Bee-sting its remedies and therapeutical effects.

»30 Generalities.

„31 Treatment of bees.

$m .311$ so as not to run risks.

$\$ .312$ to drivo bees from combs; smoking.

".32 How to open hives and remove and replace frames.

".33 Where and how to find the Queen, and way of handling her.

»34 Where and how to find young and old bees.

».35 How to get rid of fertile workers.

"38 Bee-sting and its therapsutical effects.

».39 Rem ¿dies for beø-stings.

„.4 Methods of uniting stoclis. Cure of Queenless stocks. Strengthening weak slucks.

»40 Generalities.

»41 Uniting slocks, various melhods.

».42 Care of orphan stocks.

».43 Strengthening wesk hives.

„.5 Methods of favouring or preventing the increase of stocks. Feeding, when stores deficient or stimulating. Robbing.

».50 Generalities.

๓.51 Means of favouring the increase of stocks.

„52 Means of checking brood rearing.

.53 Means of preventing the excessive breeding of drones.

n.54 Feeding stocks of bees.

».541 Feeding when stores deficient.

".542 Slimulating feeding.

.55 Rubbing. 
".6 Care of hives during the year. Profits" of beekeeping. Enlargement of brood nest. Spring and autumn inspections. Winiering. The honey harvest.

»60 Generalities.

».61 Hives during the period of wintering; during that of waking up; during and after the principal flowering season.

"611 Hives during the period of wintering.

๓612 Hives during the period of preparation for the harvest. »6121 Spring inspection.

„612. Contraction and enlargement of the brood nest. Concentration of the hive's strength. Management of bee-hives kept with view to profit.

".613 Hives during the principal flowering season. n.6131 Honey harvest.

»614 Hives after the principal flowering season. n.6141 Wintering.

»62 Means of deriving profit from hives.

».63 Hives during the various months of the year, and in various countries.

»631 During the months of November, December, January and February.

ఎ.6310 Generalities.

».6311 During November.

".6312" December.

$\$ .6313$ " January.

》6314 $》 \quad$ February.

".632 During the months of March, April, May aud June. ».6320 Generalities.

๓.6321 During March.

„.6322 " April.

$\$ .6323 \gg$ Nay.

$1.632 \% "$ June.

».633 During the months of July, August, September and October.

».6330 Generalities.

ᄁ.6331 During July.

$" .6332 "$ August.

„.6333 "September.

》.6334 " October.

"6f Hives on scales, its significance and discussions on the subject. 
„.7 Rearing and changing Queens. Culting out and inserling Queen cells. Introduction of strange Queens and Queen cells.

»70 Generalities.

».71 Favourable time for rearing Queens.

n.72 How to obtain royal cells. Rules for choosing the same: how to remove and insert them in the combs.

-.73 Inlroduction of royal cells and Queens in hives.

๓.74 Various methods of rearing Queens.

„741 Rapid methois for small apiaries.

»742 Method for substituting a Queen for an infirm one.

»743 By means of nuclei.

».744 With Queen nurseries.

\$.745 Various methods.

»75 Favourable season for changing the Queen.

".8 Formation of stocks. Natural and artificial swarms; hiving and treatment; methods of preventing swarming. Means of limiting the number of stocks. Iinproing the. race. Seletion of breeds.

»80 Generalities.

๓81 Naturaì swarms.

$\rightarrow .811$ First swarm.

».812 After swarms or casls.

".82 Taking swarms and how to hive them.

».83 Uniting swarms.

184 Artificial swarms.

$\gg .840$ Generalities.

».841 By flying bees from other hives.

$» .842$ By means of various frames of brood and bees, taken from several hives.

$\gg .843$ By division.

$\$ .844$ By brushing off bees from combs.

$» .845 \mathrm{By}$ means of nuclei and other weak stocks.

$\gg .846$ By natural swarming.

$\gg .849$ Various.

ఐ85 Gure to be bestowed on hives which have swarmed and on swarms. 
».86 Means of preventing swarming.

„.87 Means of limiting the number of hives.

»88 How the bee race can be improved. How to rapidly obtain selected drones.

"9 Trade relating to bees. Transferring bees. Aqricultural effects and bee produce. Uses and applications of these and their commercial value. Bee chemistry and metenrology.

».90 Generalities.

$\rtimes .91$ Acquisition and sale of bees and hives.

».92 Moving of stocks and apiaries.

$\gg .93$ Transferring.

»9i Wax. Its composition. Special qualities: adulteration, substitutes, uses and trade.

¥.941 Special qualities of wax : source, composition.

$\gg .942$ Melting: purification, moulds.

$\gg .933$ Keeping.

$\gg .944$ Uses.

$\gg .945$ Adulteration. Substitutes.

»946 Trade.

".95 Honey. Composition, qualitios, extraction, purification preservation, adulteration, uses and trade.

$\gg .951$. Composition.

»952 Extraction - Purification.

».953 Various qualities of honey.

".954 Preservation.

.955 Uses. Prôducts derived from honey.

\.9531 Uses of honey for the table.

$1.9552 》 0$ as frod.

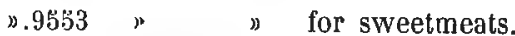

》95\%4 Medicinal uses.

๓.9556 Products derived from honey.

".95561 Mead.

$\leadsto .95562$ Wine made with an addition of honey.

».95563 Honey vinegar.

$\$ .95564$ Aleohol from honey.

»956 Adulterations. Subștitutes.

».957 Trade. Transport. 
\.96 Pollen and propolis. Composition, characters, 'substitutes and uses.

๓.97 Bee chemistry.

„.98 Bee meteorology, Monthly reports.

".99 Agricultural effects of bees.

I did not give greater extension to these tables, as those given seemed to me sufficient for a good classification without too many subdivisions.

These tables, however, in the absence of trial, must not be considered free from defects: experience must give sugyestions and I am sure that when the practical classification of the many articles in various periodicals is undertaken, many gaps will be found and therefore we shall have to make additions, to map out, render accurate and more clearly distinct the various groups into which our science must bo divided. Such additions and further elucidations must however always be effected without disturbing the numbering already made.

The editors of periolicals, or those who first set themselves to this work, which hitherto has not been proposed for our apiculture branch, nor in fact for any periodical, will be the first to experience what is wanting and to fill up such gaps.

Thus the various editors of periodicals having completed the classifying tables referring to the subject under discussion, and having submitted same to the Bruxelles International Bibliographic Institute, they can be made known to the whole world, as was Melvil Dewey's idea, so that already as stated, with an ordinary catalogue, any diligent student can and should be able to obtain. all requisite knowlodge and at the same time, make known the intellectual productions of his own and other countries.

Genoa, 31 March 1902.

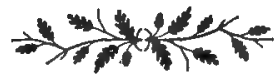






$x^{2}+2$

m 